\title{
Прохання як жанр офіційно-ділової комунікації у релігійному дискурсі
}

\section{Request as a Genre of Official Business Communication in Religious Discourse}

Богдана Іоанівна Дрофяк

(Київ, Україна)

\section{Абстракт:}

У статті здійснено аналіз різновиду текстів Прохання - одного із жанрів офіційно-ділової комунікації у релігійному дискурсі. Розроблені класифікації текстів Прохань відповідно до змісту та потенційних учасників комунікативних актів. Розглянуто структуру, мовні кліше, усталені лексико-синтаксичні звороти, семантико-синтаксичні відношення, особливості текстотворення жанру Прохання.

\section{Ключові слова:}

офіційно-ділова комунікація; релігійний дискурс; жанри офіційно-ділових текстів; оформлення документів; мовні кліше; Прохання

\begin{abstract}
:
The article analyzes the variety of texts of the Request-one of the genres of official business communication in religious discourse. The structure, language clichés, established lexical-syntactic inversions, semantic-syntactic relations, peculiarities of text-making of the genre of request are considered. According to the content of the Request we distinguish: request for the administration of the Sacrament; request for staffing; requests for awards; a request to establish a religious organization; requests for different needs; request for education in a theological school.
\end{abstract}


According to the rank of participants in communicative acts, we record the following types of Requests: when the addressee is lower in rank or status than the addressee (clergy-clergy, laity-representatives of the church hierarchy); communication between equals (priest-a priest equal to him in rank); requests from the highest to the lowest.

\section{Key words:}

official business communication; religious discourse; genres of official business texts; registration of documents; language clichés; the Request

В останні десятиліття питання релігійного дискурсу привертають посилену увагу лінгвістів. Це пов'язано із процесом відродження церковно-релігійного життя українців, створенням єдиної Православної Церкви України, її потребою розвиватися як на внутрішньорелігійному, так і на зовнішньорелігійному рівнях.

Релігійні стильові жанри, розвиток яких актуалізувався в умовах незалежної держави й повноцінного функціонування української мови, орієнтовані на вироблення нормативних, стандартизованих текстів.

Дослідження релігійного (сакрального, конфесійного) стилю в історії української мови здійснювали і здійснюють мовознавці: І. Огієнко (переклади релігійних і богослужбових текстів), О. Горбач (особливості мовостилю Святого Письма), В. Німчук (правописні проблеми релігійних текстів), Н. Бабич (проповідницький підстиль релігійного стилю), М. Скаб (виявлення апеляції в сакральних текстах), А. Ковтун (взаємодія релігійного стилю із художнім), О. Мирончук (тематичні групи лексики в релігійному стилі) Н. Пуряєва, С. Бібла (формування української церковної термінології та її варіантність) та ін.

Проте науковці не зверталися до вивчення офіційно-ділової комунікації релігійного дискурсу. Зазвичай релігійний стиль розуміють як сакральну функцію мови, як комунікацію людей із вищими силами. До цього спілкування належать молитви, богослужіння, інформація, яку отримують віряни з релігійних книг. Як і будь-яка інша організація, Церква також забезпечує комунікацію людей у цій сфері. $€$ дві форми такої комунікації: усна форма - спілкування із духовними наставниками, релігійні зустрічі тощо та письмова - звернення, прохання, ділове листування. Саме практика письмового комунікування зумовлює потребу в комплексному лінгвістичному дослідженні офіційно-ділових текстів, їх стандартизації та уніфікації.

Серед документів, пов’язаних із діяльністю релігійних організацій, розрізняємо: документи про заснування релігійних організацій (статут, протокол, 
звіт), про кадрове забезпечення (указ), участь у Таїнствах (свідоцтво), про відзначення богослужбовими нагородами та відзнаками (грамота, Благословенна грамота, посвідчення), підтвердження фактів (довідка), а також офіційно-ділова комунікація із різних потреб (розпорядження, листи, запрошення, записки, прохання).

Оскільки в офіційно-діловій комунікації релігійного дискурсу є документи, які вирізняються характерною структурою, особливостями текстотворення, усталеними зворотами, семантико-синтаксичними відношеннями між словами, мовними кліше, виникає проблема лінгвопрагматичного аналізу перелічених вище офіційно-ділових документів з погляду їх стилістичного оформлення.

Мета написання статті - комплексний лінгвостилістичний аналіз тексту Прохання як однієї із форм офіційно-ділової комунікації у релігійному дискурсі.

Реалізація поставленої мети передбачає розв'язання таких завдань:

- здійснити класифікацію текстів Прохання з погляду зафіксованої в документах церковної ієрархії адресата/адресанта, а також щодо суті порушеної проблеми;

- проаналізувати типові структурні ознаки тексту Прохання.

Джерелами дослідження є оприлюднені та архівні офіційно-ділові документи, зокрема Прохання, написані адресантами впродовж останніх десятиліть у межах Православної Церкви України (до 2018 року - Української православної церкви Київського патріархату).

В оформленні офіційно-ділових паперів релігійних організацій переважають такі документи, які відповідають нормативно-правовим вимогам а саме: Постанові Кабінету міністрів України № 55 від 17 січня 2018 року «Деякі питання документування управлінської діяльності», Національному стандарту України ДСТУ 4163-2003 та Наказу Міністерства юстиції України № 10о0/5 від 18 червня 2015 року «Про затвердження Правил організації діловодства та архівного зберігання документів у державних органах, органах місиевого самоврядування, на підприємствах, в установах і організаціях».

Проте у перелічених стандартах не знайдемо правил оформлення такого документа, як Прохання, який використовують в офіційно-діловій комунікації релігійного дискурсу.

За свідченнями дослідників, форма прохання у діловодстві з'являється у другій половині XVIII століття і за своєю метою написання, формою і структурою відповідає «чолобитним» ${ }^{1}$.

1 MAJOROV,A. (2006): Očerki leksiki regional'noj delovoj pis’mennosti XVIII veka. Moskva: «Azbukovnik», 2006, s. 40. 
В Академічному тлумачному словнику української мови знаходимо таке визначення терміна «чолобитна»: «заява, скарга або прохання від окремої особи чи соціальної групи, яку подавали до місцевих чи центральних органів управління на Україні і в Росії в XV - на початку XVIII ст.» ${ }^{2}$. Водночас у цьому словнику поняття «прохання» $є$ багатозначним, одне із значень яких відповідає терміну, що використовують в офіційно-діловій комунікації: «письмове клопотання, заява, складена за офіційно встановленою формою». ${ }^{3}$

У сучасному діловодстві релігійного дискурсу Прохання - це здебільшого рукописний документ, який передбачає звернення адресанта до адресата з метою надання благословення (дозволу) на конкретні дії.

Відповідно до змісту Прохання розрізняємо:

- прохання про здійснення Таїнства;

- прохання про кадрове забезпечення;

- прохання про нагородження;

- прохання про заснування релігійної організації;

- прохання з різних потреб;

- прохання про отримання освіти у духовному навчальному закладі.

Оформлення документа відповідає всім вимогам щодо розташування тексту на аркуші паперу. Зокрема, у верхньому правому куті сторінки розміщені реквізити з інформацією про адресата (ім'я та посада священнослужителя, до якого скеровується документ) та адресанта (ПІБ - прізвище, ім'я, по батькові, адреса автора документа). Відомості про найменування посади та адресата записують у давальному відмінку (Митрополиту Київському і всієї України Епіфанію). Якщо Прохання адресоване представнику чернецтва - рідко називають прізвище, ще рідше - по батькові.

Відповідно до сану учасників комунікативних актів фіксуємо такі типи Прохань:

- коли адресант нижчий за саном або статусом за адресата (священнослужителі - священнослужителі, миряни - представники церковної ієрархії);

- комунікування між рівними за саном (священнослужитель - рівний йому за саном священнослужитель);

- прохання від вищого за саном до нижчого. Таких випадків є вкрай мало. Однак таке явище можемо спостерігати тоді, коли вищий за саном звертається із проханням до нижчого за саном, але вищого за посадою

2 BİLODİD, İ. K.: Slovnyk ukrajins'koji movy: $v 11$ tt. AN URSR. İnstytut movoznavstva. Kyjiv: Naukova dumka, 1970-1980. Tom 11, 1980, s. 349 .

3 BİLODİD, İ. K.: Slovnyk ukrajins'koji movy: $v 11$ tt. AN URSR. İnstytut movoznavstva. Kyjiv: Naukova dumka, 1970-1980. Tom 8, 1977, s. 335. 
(Ректору Київської Православної богословської академії протоієрею Олександру Трофимлюку / викладача кафедри богослів'я архієпископа Чернігівського і Ніжинського Євстратія).

Відповідно до цих типів можемо виокремити різні форми номінації титулування церковної ієрархії, яку традиційно прописують в графі адресата. Щодо використання найменувань адресата комунікації простежуємо такі закономірності: в офіційно-протокольному спілкуванні кожному титулу священнослужителя відповідає окреме титулування з усталеною мовною конструкцією. Наприклад, якщо йтиметься про вселенського патріарха, додається префікс на позначення вищого ступеня порівняння все- (Його Всесвятості...). Пишучи текст Прохання патріархові, вживають конструкцію Його Святості Святійшому патріарху... Написання Прохання митрополитові, який одночасно є главою Церкви, передбачає вживання номінації блаженнійший (Блаженнійшому митрополиту Київському і всієї України Епіфанію). Якщо митрополит не є главою церкви, достатньо вжити конструкцію Його високопреосвященству, високопреосвященнійшому... або ж коротку форму найменування адресата високопреосвященнійшому... Оформлення Прохання єпископові чи архієпископові передбачає використання титулу преосвященство. До нижчих за рангом протоієрея чи ієрея відповідно вживають такі усталені словосполучення, як Його високопреподобію Високопреподобному або ж Його преподобію Преподобному ${ }^{4}$.

Зазначаючи найменування адресанта, використовують конструкції у формі родового відмінка без зазначення титулів, а тільки з інформацією про посаду, ім'я та прізвище священнослужителя або мирянина (настоятеля Свято-Покровського храму с. Мамаӥвці протоієрея Іоана Чокалюка). Також іноді може бути вказаний контактний телефон та зазначена адреса проживання.

Проте в сучасних офіційно-ділових документах релігійного дискурсу помічаємо тенденцію спрощувати форми апеляції до адресата, напр. замість Його Високопреосвященству високопреосвященнійшому митрополиту Іоану, Голові Синодального управління у справах військового духовенства дедалі частіше трапляються форми написання адресата за найменуванням посади та саном священнослужителя: Голові синодального управління у справах військового духовенства митрополиту Іоану (Яременку).

Посередині документа розміщена назва документа (Прохання). 3 абзацу викладено основний текст документа, який є лаконічним, займає не більше двох-трьох абзаців. Розпочинається усталеною формою «Прошу вашого благословення на...» або «Прошу благословення Вашого Високопреосвященства...»

4 FEDORJUK, M.: Konfesijnist' jak kryterì variantnostì formul movlennjevoho etyketu. $<\mathrm{http}: / / \mathrm{nbuv}$. gov.ua/j-pdf/Nvchnusf_2013_697-699_39.pdf>. [online]. [cit. 12. 12. 2013]. 
У Словнику-довіднику В. В. Жайворонка знаходимо таке тлумачення терміна «благословення»: згода, дозвіл, схвалення; ... виражається через «висловлення блага (добра)» чи «благе (добре) словлення», через побажання добра з вірою, в иерковному обряді особливо благодійне перше особисте єпископське благословення 5 .

Усталений зворот із семантикою релігійного стилю просити благословення в аналізованих текстах сполучається: а) 3 дієсловом у формі інфінітива (Прошу вашого благословення залишити викладання курсу «Історія Української Православної Церкви»...), б) з прийменниково-іменниковою конструкцією, в якій віддієслівний іменник також передає значення дії (Прошу вашого благословення на нагородження орденом святого Миколая Чудотвория..., Прошу вашого благословення на одруження...).

Водночас фіксуємо тексти документів без зазначеного звороту, в яких відповідна семантика передана віддієслівним іменником прохання, шо сполучається з дієсловом - назвою дії, про яку просять (Звертаюся до вас від імені духовенства та віруючих Івано-Франківської єпархії.. з проханям внести на розгляд засідання Собору питання про святкування Далешівської ікони Божої матері $і$ датою святкування благословити 21 червня із внесенням цієї дати у церковний календар; Ваше Преосвященство, повідомляємо вас, що 27 лютого 2019 року відбулися збори релігійної громади храму Різдва Пресвятої Богородиці... Тому просимо Ваше Преосвященство прийняти нашу релігійну громаду... до складу Закарпатської єпархї̈ Православної Церкви України).

Подекуди іншу форму має текст Прохання про хіротонію. Особа, яка виявила бажання бути рукопокладеною в сан священника, зокрема з числа студентів духовних навчальних закладів, пише Прохання на ім'я єпархіального архієрея, в канонічному підпорядкуванні якого перебуває цей заклад і який здійснюватиме хіротонію над студентом. У тексті документа він просить «благословення на рукопокладення» в сан диякона чи священника, оскільки має «щире бажання послужити церкві Христовій» і зі свого боку обіцяє «бути вірним сином Православної Церкви Украӥни». Але оскільки студент безпосередньо не може звернутися до єпархіального єпископа, він до цього Прохання пише ще одне на ім'я ректора духовного навчального закладу, якого просить поклопотатися перед єпархіальним єпископом про його рукопокладення. Це Прохання починають усталеною конструкцією «Прошу вашого ходотайства перед...». Так засвідчують певну ієрархічність осіб. Зі свого боку, ректор духовного навчального закладу, отримавши зазначені вище документи, пише Рапорт на ім'я єпархіального єпископа, якого просить здійснити хіротонію над студентом і переадресовує йому також і Прохання студента.

5 ŽAJVORONOK, V.: Znaky ukrajins'koji etnokul'tury: Slovnyk-dovidnyk. Kyjiv: Dovìra, 2006, s. 41. 
Тексти Прохання різні за обсягом. У деяких адресант логічно викладає узгоджену інформацію, передаючи її структурами з причиново-наслідковими зв'язками, напр.: Прошу вашого Високопреосвященійшого благословення прийняти мене та парафію на честь Успіння Божої Матері ... до числа ввірених вашому опікуванню парафій, що переходять від колишньої Української Православної Церкви до складу Православної церкви України. Також за потреби до тексту Прохання долучають необхідні додаткові документи, які пояснюють, доповнюють основний зміст документа. Вони можуть бути оформлені як супровідний лист.

В основному тексті Прохання широко представлені релігійні терміни й термінологічні сполуки, що стосуються статусу церкви, загальних назв релігійно-культових понять: Прошу вашого благословення надати монастирю на честь Всіх святих землі украӥнської статусу ставропігійного; Прошу благословення Вашого Високопреосвященства на видачу посвідчення на підтвердження мого канонічного статусу в лоні Украӥнської Православної Церкви. Серед них, зокрема, терміни - назви Таїнств (прошу Вашого благословення на звершення Таїнства Хрещення), терміни й термінологічні сполуки на позначення одягу священнослужителя (Прошу вашого благословення на отримання підрясника), терміни - найменування релігійних свят (Прошу вашого благословення на участь у богослужінні з нагоди престольного свята парафї Різдва Христового м. Чернівці), терміни й термінологічні сполуки - назви церковних нагород та відзнак (Прошу Вашого благословення нагородити наперсним хрестом таких священників Кічманської єпархї; Прошу вашого благословення нагородити медалями «За жертовність і любов до України» таких військовослужбовців... тощо.

Форма підпису у тексті Прохання також має свої особливості, відмінні від офіційно-ділової комунікації. Підпис складається із найменування посади особи, яка підписує документ (повного - якщо документ надрукований не на бланку, скороченого - на документі, надрукованому на бланку), особистого підпису, імені і прізвища (Голова Синодального управління військового духовенства митрополит Іоан). Також існує форма вираження шанобливого та прихильного ставлення до адресата. Коли йдеться про звернення до рівного за саном священнослужителя, використовують таку форму підпису: 3 любовю у Христі, ваш співбрат...; 3 повагою і братською любов'ю або ж Прошу ваших святих молитов...; З Закликом благословення Божого...

Якщо Прохання було висловлене від нижчого за саном до вищого, вживають форму підпису із використанням типових означень. Наприклад, Вашого високопреподобія смиреннійший послушник...; Вашої святості смиренний послушник і постійний богомолець... та інші. 
Ще один реквізит текстів офіційно-ділової комунікації - дата написання документа. У Проханні дата зазначають за юліанським календарем із скороченням «р. Б.», що означає року Божого.

Отже, жанр Прохання як текст офіційно-ділової комунікації у релігійному дискурсі має свої змістові й формальні ознаки. Хоча зовнішня форма викладу інформації і нагадує офіційно-ділові папери, що відповідають нормативно-правовим вимогам, проте в них наявні мовно-структурні (лексичні, синтаксичні, текстові) ознаки релігійного стилю, які виявляються в номінації адресатів/адресантів, усталених словосполученнях, мовних кліше, що відрізняють текст Прохання від звичного діловодства. Це визначає потребу систематизувати, уніфікувати та стандартизувати мову цього документа, запропонувати єдиний мовний стандарт офіційно-ділової комунікації у релігійному дискурсі.

\section{Література:}

BABYČ, N.: Praktyčna stylistyka ì kul'tura ukrajins'koji movy. L'vìv: Svìt, 2003. ISBN 966-8658-43-2.

BİLODİD, İ. K.: Slovnyk ukrajins'koji movy: $v 11 \mathrm{tt}$. AN URSR. İnstytut movoznavstva. Kyjiv: Naukova dumka, 1970-1980. Tom 8, 1977.

BİLODİD, İ. K.: Slovnyk ukrajins'koji movy: $v 11 \mathrm{tt}$. AN URSR. İnstytut movoznavstva. Kyjiv: Naukova dumka, 1970-1980. Tom 11, 1980.

FEDORJUK, M.: Konfesijnist' jak kryterij variantnostì formul movlennjevoho etyketu. <http://nbuv.gov.ua/j-pdf/Nvchnusf_2013_697-699_39.pdf>. [online]. [cit. 12. 12. 2013].

HLUŠČYK, S. - DYJAK, O. - ŠEVČUK, S.: Sučasnì dillovì papery. Kyjiv: A. S. K., 2008. ISBN 978-966-539-533-1.

KOČAN, İ.: Linhvistyčnyj analiz tekstu. Kyjiv: Znannja, 2008. ISBN 978-966-346-591-3. MAJOROV, A. (2006): Očerki leksiki regional'noj delovoj pis'mennosti XVIII veka. Moskva: «Azbukovnik», 2006. ISBN 5-91172-002-7.

Nakaz Ministerstva justyciji Ukrajiny No 100/5 vid 18 červnja 2015 roku «Pro zatverdžennja Pravyl orhanizacìji dilovodstva ta archivnoho zberihannja dokumentiv u deržavnych orhanach, orhanach miscevoho samovrjaduvannja, na pidpryjemstvach, $v$ ustanovach i orhanizacijach». <https://zakon.rada.gov.ua/laws/show/zo736-15\#Text>. [online]. [cit. 18. 6. 2015]. 
Postanova Kabìnetu Mìnistrìv Ukrajiny vìd 17 sičnja 2018 roku No 55 «Dejakì pytannja dokumentuvannja upravlins'koji dijal'nosti». <https://zakon.rada.gov.ua/laws/show/ 55-2018-p\#Text>. [online]. [cit. 17. 1. 2018].

ŽAJVORONOK, V.: Znaky ukrajins'koji etnokul'tury: Slovnyk-dovidnyk. Kyjiv: Dovìra, 2006. ISBN 966-507-195-5.

\section{About the author}

\section{Bohdana Drofiak}

The National Academy of Sciences of Ukraine, Institute for Ukrainian Language, Department of stylistics, culture of language and sociolinguistics, Kyiv, Ukraine chokaliuk@gmail.com 
